Kebijakan: Jurnal Ilmu Administrasi

Volume 11, Nomor 2, Juni 2020

E-ISSN: 2656-2820

P-ISSN 1829-5762

\title{
TANTANGAN DALAM PENGEMBANGAN PROGRAM PELATIHAN BALAI DIKLAT INDUSTRI DI ERA REVOLUSI INDUSTRI 4.0
}

\author{
Udhik Pandu Tunggal Rahargo ${ }^{1)^{*}}$, Lina Miftahul Jannah ${ }^{2)}$ \\ ${ }^{1}$ Fakultas Ilmu Administrasi, Universitas Indonesia \\ Depok, Jawa Barat, Indonesia \\ panduudhik@gmail.com \\ ${ }^{2}$ Fakultas Ilmu Administrasi, Universitas Indonesia \\ Depok, Jawa Barat, Indonesia \\ linamjannah@gmail.com
}

\begin{abstract}
ABSTRAK
Balai Diklat Industri merupakan instansi di bawah Kementerian Perindustrian yang memilki tugas dan fungsi dalam penyiapan sumber daya manusia industri yang kompeten melalui program diklat berbasis kompetensi dengan konsep pelatihan, sertifikasi kompetensi dan penempatan kerja. Program diklat yang dilaksanakan dituntut untuk menyesuaikan kebutuhan industri. Implementasi industri 4.0 menuntut Balai Diklat Industri beradaptasi dengan cepat. Artikel ini bertujuan untuk menggambarkan tantangan yang dihadapi dan langkahlangkah pengembangan program diklat yang dilakukan Balai Diklat Industri dalam menghadapi era revolusi industri 4.0. Metode yang digunakan dalam pengumpulan data menggunakan studi dokumen dan literatur yang relevan dengan pembahasan. Hasil dari artikel ini berupa tantangan yang dihadapi Balai Diklat Industri dan langkah-langkah yang dilakukan dalam pengembangan program diklat, yaitu identifikasi dan pengembangan standar kompetensi, pengembangan diklat mulai dari identifikasi kebutuhan diklat, desain, pelaksanaan, sertifikasi kompetensi, penempatan kerja dan evaluasi diklat, kemudian pengembangan sdm kediklatan berupa tenaga pengajar dan pengelola diklat dan yang terakhir pengembangan sarana dan prasarana yang menunjang program diklat yang sesuai dengan kebutuhan industri 4.0
\end{abstract}

Kata Kunci: Pengembangan Diklat, Sumber Daya Manusia Industri, Era Industri 4.0

\begin{abstract}
The Industrial Training Center is an agency under the Ministry of Industry that has the duties and functions of preparing competent industrial human resources through competency-based education and training programs with the concept of training, competency certification and job placement. The implemented education and training program is required to match the needs of the industry. The implementation of industry 4.0 requires the Industrial Training Center to adapt quickly. This article aims to describe the challenges faced and the steps to develop the education and training program carried out by the Industrial Training Center in the face of the era of the industrial revolution 4.0. The method used in data collection used document studies and literature relevant to the discussion. The results of this article are the challenges faced by the Industrial Training Center and the steps taken in developing the education and training program, namely the identification and development of competency standards, the development of education and training starting from the identification of training needs, design, implementation, competency certification, job placement and evaluation of education and training. then the development of education and training human resources in the form of teaching staff and education and training managers and finally the development of facilities and infrastructure that support the education and training program in accordance with the needs of industry 4.0.
\end{abstract}

Keywords: Development of Education and Training, Industrial Human Resources, Industrial Era 4.0 


\section{PENDAHULUAN}

Kemajuan teknologi telah mengubah perekonomian dunia, salah satu sektor yang mengalami perubahan adalah sektor industri. Hal ini ditandai dengan munculnya revolusi industri generasi keempat, yang secara luas dikenal dengan revolusi industri 4.0. Dalam pelaksanaannya, revolusi industri 4.0 ini telah dimanfaatkan berbagai gabungan (konvergensi) antara teknologi informasi dan teknologi operasional yang dapat menghasilkan digitalisasi sistem produksi dan dimanfaatkannya teknologi komputasi awan (cloud computing) yang dikombinasikan dengan teknologi kecerdasan buatan (artificial intelligence), Internet of Thing (IOT), dan big data sehingga dimungkingkan terbentuknya Cyber-Physical System (CPS) dan industri cerdas (smart factory). Revolusi industri 4.0 merupakan pengembangan dari revolusi industri sebelumnya yang telah menyebabkan perubahan paradigma pada sektor manufaktur. Revolusi industri 1.0 dimulai sekitar abad 17-an dengan diperkenalkannya tenaga air dan uap yang membantu mekanisasi produksi dan peningkatan sektor pertanian. Kemudian, revolusi industri 2.0 dimulai sekitar abad 18-an dengan diperkenalkan tenaga listrik dan produksi massal pada sektor manufaktur, sedangkan revolusi industri 3.0 muncul sekitar abad 20-an dengan diperkenalkan otomatisasi, teknologi informasi, dan berbagai komponen/peralatan elektronik. Pemerintah Indonesia bertindak cepat dalam menanggapi perubahan yang cukup besar di sektor industri, yaitu melalui Kementerian Perindustrian. Dalam rangka meningkatkan daya saing industri di pasar global dan memastikan kesuksesan adopsi industri 4.0, Kementerian Perindustrian menyusun inisiatif dengan menetapkan "Roadmap Making Indonesia 4.0" dan menentukan aspirasi yang akan dicapai pada tahun 2030, yaitu menjadi 10 perekonomian terbesar dunia pada tahun 2030 dengan mendapatkan kembali keuntungan ekspor bersih, mendorong pangsa Produk Domestik Bruto (PDB) dari manufaktur, dan bersaing dalam produktivitas, sebagai hasil dari kemajuan teknologi dan inovasi. Roadmap Making Indonesia 4.0 memberikan arah dan strategi yang jelas bagi pergerakan industri Indonesia di masa yang akan datang, termasuk di lima sektor yang menjadi prioritas yaitu industri makanan dan minuman, industri tekstil dan busana, industri otomotif, industri kimia, dan industri elektronika berserta potensi teknologi berdasarkan rantai nilai. Dalam roadmap tersebut juga disebutkan lima teknologi dasar industri 4.0, yaitu Artificial Intelligence (AI), Internet of Things (IoT), Wearables (Augmented Reality - AR and Virtual Reality - VR), Advanced Robotics, dan 3D printing. Roadmap Making Indonesia 4.0 secara resmi diserahkan oleh Menteri Perindustrian Airlangga Hartarto kepada Presiden Joko Widodo dalam acara peluncuran Making Indonesia 4.0 tanggal 4 April tahun 2018. Presiden juga menyampaikan bahwa "Selain menciptakan lapangan kerja baru, implementasi Industri 4.0 di Indonesia harus memastikan pertumbuhan secara inklusif, yang melibatkan seluruh lapisan ekonomi masyarakat," (Jakarta, 4 April 2018).

Sementara itu, industri juga sudah mulai bertransformasi menuju industri 4.0. Kementerian Perindustrian Republik Indonesia telah menyusun sebuah indeks yang diberi nama Indonesia Industry 4.0 Readiness Index atau yang disingkat dengan INDI 4.0, yaitu indikator penilaian tingkat kesiapan industri di Indonesia dalam menerapkan teknologi era industri 4.0. Pada dasarnya INDI menilai kesiapan dari 5 pilar, yaitu teknologi, operasi pabrik, manajemen dan organisasi, orang dan budaya, serta produk dan layanan. Berdasarkan asesmen yang dilakukan Kementerian Perindustrian per 10 april 2019 terhadap sampling 323 perusahaan rata-rata perusahaan tersebut tergolong kedalam level "kesiapan sedang" yang artinya perusahaan sudah mulai bertransformasi ke industri 4.0. Penyiapan 


\section{Kebijakan: Jurnal Ilmu Administrasi \\ Volume 11, Nomor 2, Juni 2020 \\ E-ISSN: 2656-2820 \\ P-ISSN 1829-5762}

sumber daya manusia industri yang kompeten menjadi prioritas dalam menghadapi implementasi Industri 4.0. Seperti halnya yang dikatakan oleh Menteri Perindustrian, Airlangga Hartarto kepada media, "Di dalam Roadmap Making Indonesia 4.0, salah satu program prioritasnya adalah peningkatan kualitas SDM. Sebab, talent menjadi kunci atau faktor penting untuk kesuksesan implementasi industri 4.0" (Jakarta, 4 April 2018). Dari pernyataan tersebut dapat disimpulkan bahwa sumber daya manusia industri menjadi kunci keberhasilan implementasi Industri 4.0. Sesuai dengan Peraturan Menteri Perindustrian R.I Nomor 40/M-IND/PER/5/2014, Balai Diklat Industri merupakan institusi pemerintah di bawah Kementerian Perindustrian yang mempunyai tugas pokok dan fungsi dalam menghasilkan sumber daya manusia industri yang kompeten dan berdaya saing melalui pendidikan dan pelatihan (diklat) berbasis kompetensi dengan konsep pelatihan, sertifikasi kompetensi dan penempatan kerja. Program yang dijalankan dituntut untuk selalu beradaptasi terhadap kebutuhan industri pada masa sekarang, sehingga dapat menghilangkan ketidaksepadanan (mismatch) antara penyediaan lulusan diklat dengan kebutuhan industri. Implementasi industri 4.0 akan berpengaruh terhadap kebutuhan sumber daya manusia industri yang dihasilkan oleh lulusan yang dihasilkan. Hal ini tentu menuntut Balai Diklat Industri beradaptasi terhadap kebutuhan sumber daya manusia industri 4.0 .

Revolusi industri 4.0 yang identik dengan digitalisasi dan otomatisasi akan mencipatakan pekerjaan-pekerjaan yang berkaitan dengan teknologi informasi. Baur dan Wee (2015) menyebutkan bahwa dalam mengimplementasikan industri 4.0 pada komponen tenaga kerja (labor), harus memenuhi; 1) kolaborasi manusia dengan robot; 2) kontrol dan kendali jarak jauh; 3) manajemen kinerja digital; dan 4) otomasi pengetahuan kerja. Sementara itu , menurut Haryono (2018), tantangan sumber daya manusia di era revolusi industri 4.0 adalah integrasi pemanfaatan internet dengan lini produksi yang memanfaatkan kecanggihan teknologi dan informasi. Karakteristik revolusi industri 4.0 ini meliputi digitalisasi, optimalisasi dan kustomisasi produksi, otomasi dan adapsi, interaksi antar mesin-manusia, nilai tambah jasa dan bisnis, automatic data exchange and communication, dan penggunaan teknologi intenet. Oleh karena itu dalam menghadapi tantangan tersebut, Balai Diklat Industri harus segera melakukan langkah-langkah nyata dalam pengembangan program diklat yang menghasilkan sumber daya manusia industri kompeten yang link and match dengan kebutuhan industri 4.0. Berdasarkan kondisi tersebut, maka peneliti tertarik untuk melakukan penelitian mengenai tantangan yang dihadapi Balai Diklat Industri dalam menghadapi revolusi industri 4.0 dan langkah-langkah seperti apa yang harus dilakukan dalam menghadapi tantangan tersebut.

\section{METODE}

Penelitian yang dilakukan merupakan jenis penelitian deskriptif, Neuman (2014) menyatakan bahwa penelitian deskriptif merupakan penelitian yang memberikan gambaran spesifik mengenai keadaan yang sebenarnya dari suatu situasi dan keterkaitan sosial. Peneliti berusaha untuk mengungkap dan mendeksripsikan tantangan dan langkah-langkah dalam melakukan pengembangan program pendidikan dan pelatihan sumber daya manusia industri dalam menghadapi revolusi industri 4.0. Sementara itu, teknik pengumpulan data yang digunakan oleh peneliti adalah pengumpulan data melalui studi dokumen dan literatur yang relevan dengan penelitian yang akan dilakukan sehingga memudahkan dalam proses analisis masalah.

\section{PEMBAHASAN}

Pendidikan dan Pelatihan (Diklat) memiliki peran penting dalam pengembangan sumber daya manusia guna meningkatkan kemampuannya demi mencapai tujuan organisasi. Diklat merupakan 
Kebijakan: Jurnal Ilmu Administrasi

Volume 11, Nomor 2, Juni 2020

E-ISSN: 2656-2820

P-ISSN 1829-5762

solusi bagi suatu organisasi dalam mengatasi suatu kesenjangan kompetensi yang terjadi. Diklat yang dilaksanakan oleh Balai Diklat Industri merupakan pelatihan berbasis kompetensi dengan konsep pelatihan, sertifikasi kompetensi dan penempatan kerja. Wu (2013) menjelaskan bahwa pelatihan berbasis kompetensi berfokus pada penguasaan dan peningkatan kompetensi yang mencakup pengetahuan keterampilan dan sikap yang telah disesuaikan dengan standar kompetensi yang ditetapkan sehingga pelatihan akan lebih terstruktur dan terarah. Berikut ini adalah gambaran penyelenggaraan diklat sumber daya manusia industri yang dilaksanakan oleh Balai Diklat Industri Kementerian Perindustrian.

Gambar 1. Konsep Penyelenggaraan Diklat SDM Industri Balai Diklat Industri

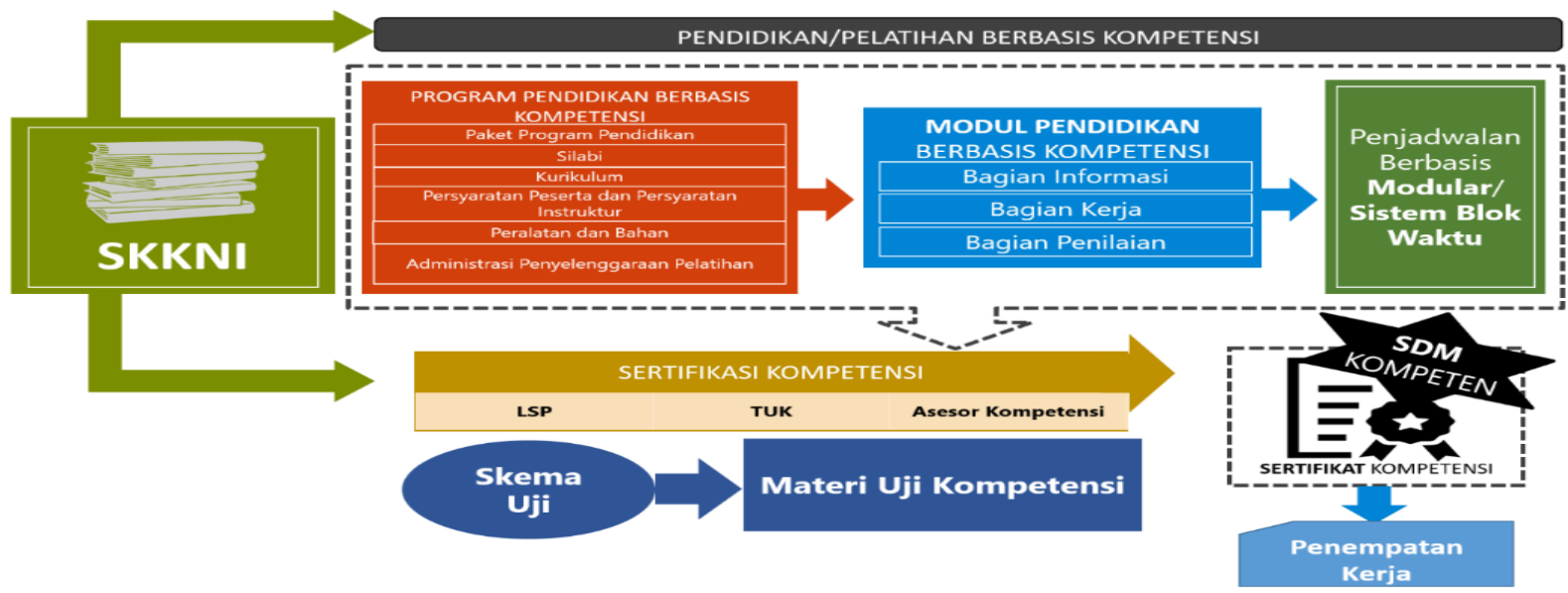

Balai Diklat Industri dalam hal penyelenggaraan diklat sebagaimana diatur dalam Peraturan Menteri Perindustrian R.I nomor 40/M-IND/PER/5/2014 tentang Organisasi dan Tata Kerja Balai Pendidikan dan Pelatihan Industri Kementerian Perindustrian terdiri dari 7 (tujuh) Balai Diklat Industri yang tersebar di beberapan wilayah Indonesia dengan spesialisasi masing-masing. Tabel 1 berikut menggambarkan jenis diklat dan jumlah peserta diklat pada tahun 2019.

Tabel 1. Data Diklat Balai Diklat Industri Tahun 2019

\begin{tabular}{|c|l|l|c|}
\hline NO & \multicolumn{1}{|c|}{ Unit Kerja } & \multicolumn{1}{|c|}{ Nama Diklat } & Jumlah Peserta \\
\hline 1. & $\begin{array}{l}\text { Balai Diklat Industri } \\
\text { Jakarta }\end{array}$ & $\begin{array}{l}\text { Operator Garmen, Supervisor Garmen, Operator } \\
\text { Tekstil, Membatik, Quality Control Garmen }\end{array}$ & 12.300 \\
\hline 2. & $\begin{array}{l}\text { Balai Diklat Industri } \\
\text { Yogyakarta }\end{array}$ & $\begin{array}{l}\text { Operator Industri Produk Plastik, Operator } \\
\text { Pembuatan Alas Kaki }\end{array}$ & 7.344 \\
\hline 3. & $\begin{array}{l}\text { Balai Diklat Industri } \\
\text { Surabaya }\end{array}$ & $\begin{array}{l}\text { Operator Garmen, Supervisor Garmen, } \\
\text { Elektronika }\end{array}$ & 10.860 \\
\hline 4. & $\begin{array}{l}\text { Balai Diklat Industri } \\
\text { Medan }\end{array}$ & Diklat Bidang Produk Kelapa Sawit & 4.035 \\
\hline 5. & $\begin{array}{l}\text { Balai Diklat Industri } \\
\text { Padang }\end{array}$ & $\begin{array}{l}\text { Diklat Bidang Bordir dan Merancang Busana } \\
\text { Balai Diklat Industri }\end{array}$ & $\begin{array}{l}\text { Diklat Bidang Kakao, Rumput Laut dan } \\
\text { Kemasan }\end{array}$ \\
\hline 7. & $\begin{array}{l}\text { Balai Diklat Industri } \\
\text { Denpasar }\end{array}$ & Diklat Bidang Animasi & 2.080 \\
\hline
\end{tabular}


(Laporan Kinerja Badan Pengembangan SDM Industri Kementerian Perindustrian Tahun 2019)

Berdasarkan table diatas, apabila dibandingkan dengan sektor prioritas dalam impelemntasi industri 4.0 yang terdapat dalam Roadmap Making Indonesia 4.0 yang meliputi industri makanan dan minuman, kimia, otomotif, tekstil garmen dan elektronika baru terdapat dua sektor yang sudah ada spesialisasinya, akan tetapi juga belum terlihat adanya jenis diklat yang menggambarkan teknologi industri 4.0, seperti Artificial Intelligence (AI), Internet of Things (IoT), Wearables (Augmented Reality - AR and Virtual Reality - VR), Advanced Robotics, dan 3D Printing. Hal ini tentunya menjadi tantangan bagi Balai Diklat Industri untuk melakukan penyesuaian program diklat dan langkah awal yang dilakukan adalah melakukan pengembangan program diklat. Pengembangan program diklat yang dilakukan Balai Diklat Industri di lingkungan Kementerian Perindustrian dilakukan dengan langkah-langkah berikut:

\section{Pengembangan Standar Kompetensi Kerja Nasional Indonesia (SKKNI)}

SKKNI adalah rumusan kemampuan kerja yang mencakup aspek pengetahuan, keterampilan dan/atau keahlian serta sikap kerja yang relevan dengan pelaksanaan tugas dan syarat jabatan. Pengembangan SKKNI dapat dilakukan dengan du acara, yaitu penyusunan SKKNI baru atau kaji ulang SKKNI yang sudah ada guna memelihara validitas dan reliabilitasnya. Tahapan yang harus dilalui dalam pengembangan SKKNI sesuai pedoman dari Kementerian Ketenagakerjaan, yaitu pembentukan tim perumus dan tim verifikasi, perumusan SKKNI, verifikasi internal, rapat prakonvensi RSKKNI, verifikasi eksternal, rapat konvensi RSKKNI dan penetapan SKKNI. SKKNI berisi kompetensi-kompetensi yang ada pada suatu bidang keahlian, yang dituangkan dalam format peta kompetensi dan uraian unit kompetensi. Dalam pengembangan program diklat yang link and match dengan implementasi industri 4.0, perlu dilakukan identifikasi terhadap kebutuhan kompetensi industri 4.0 yang nantinya akan diterjemahkan kedalam format SKKNI. Roland Berger (2016) menyampaikan bahwa kemampuan dan kualifikasi yang harus dimiliki dalam menghadapi industri 4.0 diklasifikasikan ke dalam empat kategori utama sebagaimana dijelaskan dalam gambar 2 berikut ini.

Gambar 2. Kemampuan dan Kualifikasi SDM Industri 4.0

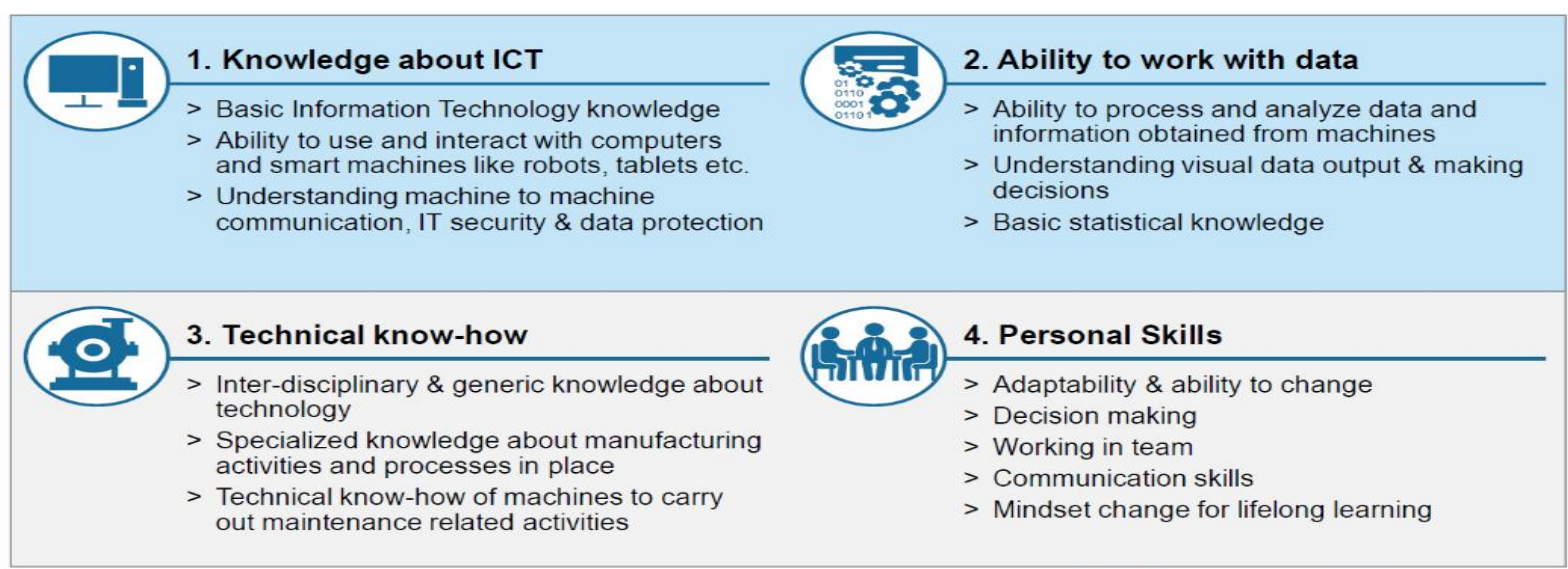

Sumber : Whitepaper Skill Development for Industry 4.0, Roland Berger

More Focus

Less Focus

Berdasarkan gambar tersebut, pengetahuan mengenai teknologi informasi dan kemampuan dalam bekerja menggunakan data menjadi prioritas yang harus dimiliki oleh SDM industri 4.0, sedangkan kemampuan teknis dan individu menjadi penunjang dalam melaksanakan pekerjaan tersebut. Oleh karena itu, dalam mengembangkan SKKNI yang berorientasi terhadap implementasi 


\section{Kebijakan: Jurnal Ilmu Administrasi \\ Volume 11, Nomor 2, Juni 2020 \\ E-ISSN: 2656-2820 \\ P-ISSN 1829-5762}

industri 4.0 harus mempehatikan kompetensi-kompetensi dari setiap bidang keahlian yang relevan dengan teknologi informasi dan kemampuan mengolah data.

\section{Pengembangan Diklat}

Pengembangan diklat merupakan hal yang sangat penting guna menyelaraskan program diklat dengan kebutuhan industri. Proses dalam pengembangan diklat menurut Armstrong (2009) terdiri dari identifikasi kebutuhan pelatihan, perencanaan program pelatihan, pelaksanaan pelatihan dan menindaklanjuti pelaksanaan pelatihan untuk mengetahui efektifitasnya. Allen (2006) juga menjabarkan melalui ADDIE Model, yaitu:

a. Analysis. Langkah awal untuk mengetahui kebutuhan pelatihan yang dilakukan penilaian terhadap organisasi, pekerjaan dan individu.

b. Design. Membuat sebuah rancangan program pelatihan yang optimal berupa tujuan pelatihan, kurikulum, instrument penilaian, materi dan alat seleksi.

c. Development. Membuat rancang bangun pelatihan oleh perancang pelatihan mengikuti desain yang telah dibuat termasuk memanfaatkan teknologi informasi.

d. Implementation. Tahapan pelaksanaan pelatihan yang merupakan proses pengajar memberikan materi yang telah ditetapkan dalam kurikulum.

e. Evaluation. Evaluasi terhadap seluruh proses rancangan pelatihan bertujuan untuk memastikan setiap tahap sistem pelatihan mendukung tujuan pelatihan.

Dari gambaran teori-teori tersebut, langkah-langkah yang dilakukan Balai Diklat Industri dalam menyusun program diklat industri 4.0 adalah sebagai berikut.

1) Identifikasi kebutuhan pengembangan diklat. Tujuan dari kegiatan ini adalah untuk menggali informasi tentang kebutuhan jumlah dan kompetensi SDM industri serta memastikan kesesuaian antara kebutuhan kompetensi SDM industri dengan SKKNI.

2) Menyusun program pelatihan berbasis kompetensi yang link and match dengan industri 4.0. Tujuan kegiatan ini adalah menentukan materi, durasi waktu dan penjadwalan pelatihan yang dibutuhkan peserta untuk mencapai kompetensi yang dibutuhkan industri 4.0.

3) Menyusun modul diklat yang berisi mengenai informasi terkait kompetensi industri 4.0.

4) Menyelenggaraan diklat SDM industri 4.0

5) Sertifikasi kompetensi lulusan diklat melalaui Lembaga Sertifikasi Profesi dengan skema sertifikasi yang sesuai standar SKKNI.

6) Menempatkan lulusan diklat yang kompeten pada perusahaan industri berdasarkan kebutuhan tiap-tiap industri.

7) Melakukan evaluasi pelaksanaan diklat. Tujuan dari kegiatan ini adalah untuk mengkaji keberhasilan pelaksanaan diklat yang terdiri dari : kesesuaian kedalaman materi dan waktu pelatihan, efektivitas pelaksanaan diklat oleh instruktur dan pengelola diklat, serta kelengkapan sarana prasarana penunjang diklat.

Dalam menentukan jenis diklat yang akan dilaksanakan didasarkan pada kompetensi pekerjaanpekerjaan baru yang ada dalam industri 4.0. Laporan dari NASSCOM-FICCI-EY (FICCI et al, 2017) memberikan gambaran mengenai kompetensi yang dibutuhkan terhadap pekerjaan-pekerjaan baru dalam era industri 4.0 sebagaimana gambar 3 berikut ini. 


\section{Kebijakan: Jurnal Ilmu Administrasi \\ Volume 11, Nomor 2, Juni 2020 \\ E-ISSN: 2656-2820 \\ P-ISSN 1829-5762}

Gambar 3. Kebutuhan Kompetensi Pekerjaan Baru

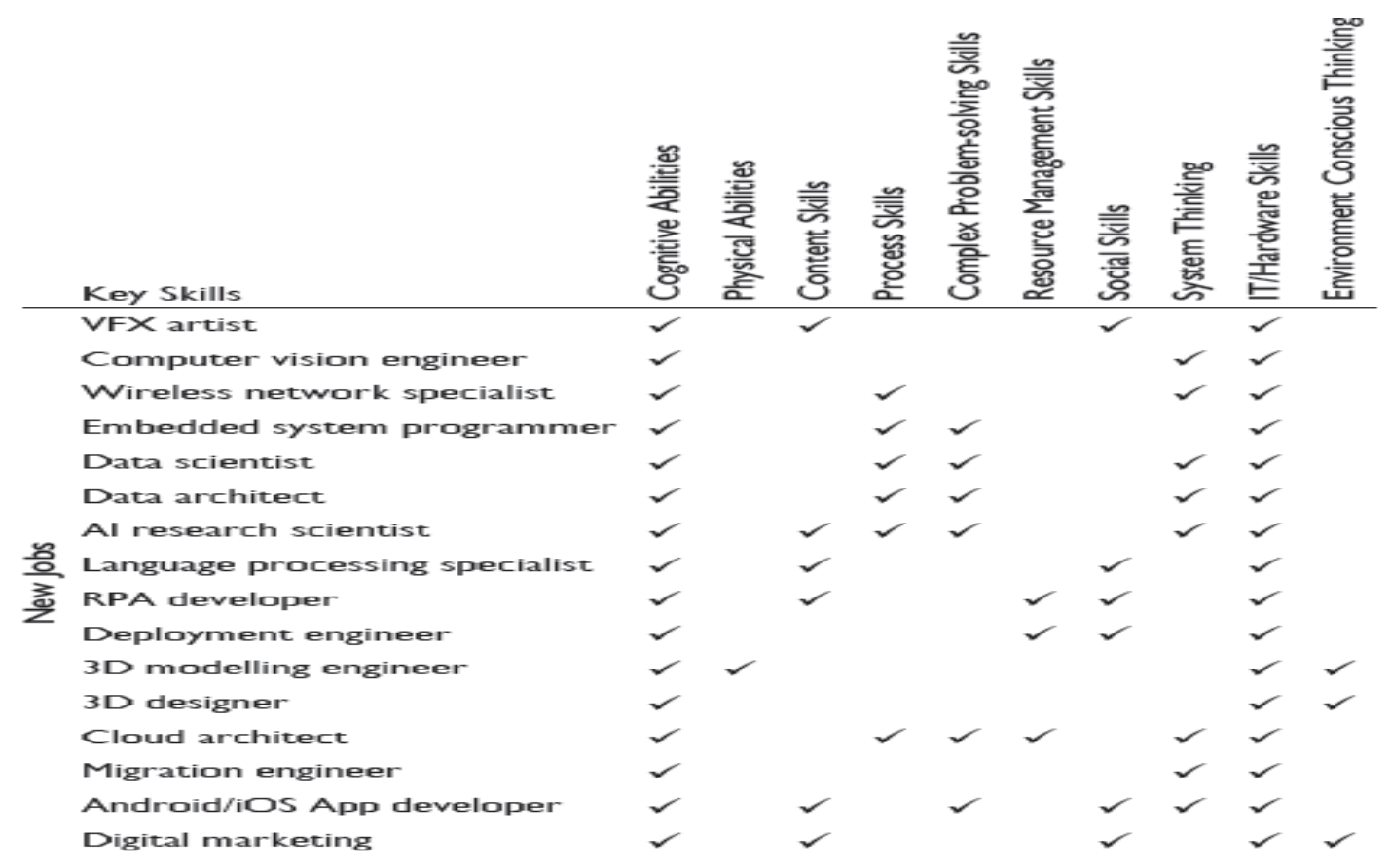

Sumber : FICCI, NASSCOM and EY, 2017

Berdasarkan gambar tersebut terdapat beberapa pekerjaan baru dengan kualifikasi kompetensi yang harus dimiliki. Hal tersebut tentunya dapat menjadi referensi dalam menentukan program diklat baru yang dibutuhkan oleh industri 4.0, disamping juga harus melakukan studi lapangan agar kompetensi yang ditentukan nantinya sesuai dengan yang dibutuhkan industri.

\section{Pengembangan Sumber Daya Manusia Diklat}

Sumber daya manusia diklat meliputi tenaga pengajar dan pengelola diklat. Tenaga pengajar Balai Diklat Industri berasal dari widyaiswara, instruktur, praktisi industri dan asosiasi industri/profesi maupun narasumber lain yang memiliki kompetensi yang sesuai. Kompetensi yang dimaksud berupa kompetensi teknis sesuai spesialisasi yang diajarkan dan kompetensi metodologi pengajaran melalui training of trainer (TOT) bagi calon tenaga pengajarnya. Sementara itu, pengelola diklat dilaksanakan oleh pegawai Balai Diklat Industri yang diputuskan oleh Kepala Balai Diklat Industri dalam kepanitiaan diklat. Tenaga pengajar dan pengelola diklat menjadi penentu keberhasilan dalam proses pembelajaran dan kompeten atau tidaknya lulusan diklat. Knowles (2005) menekankan pendidik sebagai agen perubahan yang memberikan rangsangan dan penguatan untuk belajar dan kegiatan yang sudah didesain agar peserta berubah. Oleh karena itu perlu dilakukan beberapa hal berikut guna memastikan kompetensi dari tenaga pengajar dan pengelola diklat.

a. Mengikuti program magang industri pada perusahaan industri yang sudah bertransformasi ke dalam industri 4.0

b. Meningkatankan kompetensi tenaga pengajar melalui program diklat yang sesuai dengan kompetensi yang diajaarkan.

f. Melakukan asesmen kompetensi terhadap masing-masing tenaga pengajar sesuai dengan kompetensi yang akan diajarkan, baik kompetensi teknis maupun metodologi pengajaran.

g. Meningkatkan kompetensi pengelola diklat dalam pengelolaan LSP, teaching factory, unit produksi dan penyelenggaraan diklat. 


\section{Kebijakan: Jurnal Ilmu Administrasi \\ Volume 11, Nomor 2, Juni 2020 \\ E-ISSN: 2656-2820 \\ P-ISSN 1829-5762}

\section{Pengembangan Sarana dan Prasarana Diklat}

Sarana dan Prasarana diklat merupakan infrastruktur fisik yang dibutuhkan guna menunjang pelaksanaan diklat, seperti peralatan, mesin, workshop, ruang kelas dan jaringan internet. Dalam menunjang diklat sumber daya manusia industri 4.0, sarana dan prasarana harus disesuikan dengan teknologi industri 4.0. Mashelkar (2018) menyampaikan bahwa terdapat 10 teknologi eksponensial dalam pekerjaan industri 4.0, yaitu Internet of things (IOT), Artificial Intelligence (AI) (Machine Learning), Robotics Process Automation (RPA), Virtual/Augmented/Mixed Reality, Sensors, 3D Printing, 3D Visualisation, Mobile Internet and Cloud, Big Data Analytics/Open Data, Blockchain. Sementara itu dalam Roadmap Making Indonesia 4.0 terdapat 5 teknologi dasar industri 4.0, yaitu Artificial Intelligence (AI), Internet of Things (IoT), Wearables (Augmented Reality - AR and Virtual Reality - VR), Advanced Robotics, dan 3D Printing.

Berdasarkan teknologi-teknologi tersebut, Balai Diklat Industri harus mulai memetakan teknologi yang dibutuhkan oleh masing-masing industri dan disesuaikan dengan spesialisasinya masing-masing, sehingga mempermudah dalam menentukan kebutuhan sarana dan prasarana yang dibutuhkan. Salah satu yang dapat dilakukan dalam pengembangan diklat SDM industri 4.0 terhadap sarana dan prasarana adalah dengan dibuatkannya mini plant produksi industri 4.0 yang berfungsi sebagai pusat demontrasi, riset, pengembangan, desain dan show case sekaligus untuk menyiapkan sumber daya manusia industri yang mempunyai kompetensi di bidang industri 4.0 agar mampu merancang dan mengembangkan proses produksi yang efisien menggunakan teknologi terapan yang handal untuk tercapainya lingkungan industri yang produktif serta adaptif. Selain itu perlu juga didukung oleh jaringan internet dan teknologi informasi yang memadai, sehingga proses interkoneksi antar mesin dan peralatan dapat berjalan dengan lancar.

\section{KESIMPULAN}

Keberadaan dan impelementasi Industri 4.0 membuat banyak perubahan dalam sektor industri, mulai dari cara bekerja, kebutuhan keterámpilan angkatan kerja, bahkan cara pelanggan mengkonsumsi suatu produk, demikian pula dengan cara pelaku bisnis dalam mendesain, mengolah dan memproduksi barang. Sumber daya manusia industri merupakan factor kunci dalam keberhasilan implementasi industri 4.0 tersebut. Balai Diklat Industri sebagai unit di bawah Kementerian Perindustrian yang bertugas dalam penyiapan sumber daya manusia industri yang kompeten harus bergerak cepat dalam menyesuaikan program diklat dengan kebutuhan industri saat ini, sehingga tidak terjadi ketidaksepadanan (mismatch) antara supply lulusan diklat dengan kebutuhan industri. Tantangan yang dihadapi Balai Diklat Industri cukup besar, yaitu belum adanya program diklat yang sesuai dengan kebutuhan industri 4.0. Maka dari itu, perlu dilakukan pengembangan program diklat yang baru. Langkah-langkah yang dilakukan antara lain dengan melakukan identifikasi kompetensi yang dibutuhkan guna melakukan penyusunan standar kompetensi dan kebutuhan program diklat yang akan dibuat. Setelah itu, dilakukan pengembangan diklat yang terdiri dari identifikasi kebutuhan diklat, desain program diklat, penyusunan modul, pelaksanaan diklat, sertifikasi, penempatan kerja dan evaluasi diklat. Pengembangan juga dilakukan bagi tenaga pengajar, pengelola diklat dan saranan prasarana diklat yang menunjang kebutuhan industri 4.0, sehingga lulusan diklat yang dihasilkan kompeten dan berdaya saing sesuai kebutuhan industri 4.0. 
Kebijakan: Jurnal Ilmu Administrasi

Volume 11, Nomor 2, Juni 2020

E-ISSN: 2656-2820

P-ISSN 1829-5762

\section{DAFTAR PUSTAKA}

Allen, W. Clayton. (2006). Overview and evolution of the ADDIE training system, Advance in developing human resources; 8, 4, ABI/INFORM Collection pg 430.

Armstrong, Michael. (2009). Armstrong"s handbook of human resource management practice $\left(11^{\text {th }}\right.$ ed.). London and Philadelphia: Kogen page.

Aulbur, Wilfried, Arvind, C.J \& Bigghe Rishi. (2016). Whitepaper skill development for industry 4.0: Roland Berger

A.T. Kearney. (2017). Laporan Kegiatan Penyusunan Roadmap Implementasi Industri 4.0

Badan Pengembangan Sumber Daya Manusia Industri Kementerian Perindustrian. (2019). Dasardasar industri $4.0\left(1^{\text {st }}\right.$ ed.). Jakarta.

Baur.C. \& Wee.D. (2015). Manufacturing's Next Act. McKinsey \& Company. Retrieved from https://www.mckinsey.com/business functions /operations/ ourinsights/manufacturing-next-act.

Haryono, Siswoyo. (2018). Re-Orientasi pengembangan sdm era digital pada revolusi industri 4.0. Yogyakarta: Direktora Pascasarjana Universitas Muhammadiyah.

Kagermann, H., Lukas, W.D., \& Wahlster, W. (2011). Industrie 4.0: Mitdem Internet der Dinge auf dem Weg zur 4. industriellen Revolution.http://www.vdi-nachrichten.com/ Technik Gesellschaft/Industrie-40- Mit-Internet-Dinge-Weg-4-industriellen-Revolution

Knowles, Malcolm \& Holton, Elwood F. (2005). The adulth learner $\left(6^{\text {th }}\right.$ ed.). California:Elsevier.

Laporan Akuntabilitas Kinerja Badan Pengembangan SDM Industri 2019. (2019). Jakarta

Laporan Akuntabilitas Kinerja Kementerian Perindustrian 2019. (2019). Jakarta

Mashelkar, R.A. (2018). Exponential technology, industry 4.0 and future of jobs in india, Review of Market Integration, SAGE 10(2), 138-157.

Neuman, W. L. (2014). Social research method; qualitative and quantitative methods $\left(7^{\text {th }}\right.$ ed.). London: Pearson New International.

Peraturan Menteri Tenaga Kerja dan Transmigrasi Nomor 8 tahun 2014 tentang Pedoman Penyelenggaraan Pelatihan Berbasis Kompetensi

Peraturan Menteri Perindustrian Nomor 40 tahun 2014 tentang Organisasi dan Tata Laksana Balai Diklat Industri.

Rencana Strategis Badan Pengembangan Sumber Daya Manusia Industri Kementerian Perindustrian 2020-2024. (2020). Jakarta

Wu, Jui-Lan. (2013). The study of competency-based training and strategies in the public sector: experience from taiwan. Public Personnel Management, SAGE 42(2) 259-271. 